\title{
Vascularization in Bone Tissue Engineering: Physiology, Current Strategies, Major Hurdles and Future Challenges
}

\author{
Marina I. Santos, ${ }^{*}$ Rui L. Reis
}

The lack of a functional vascular supply has, to a large extent, hampered the whole range of clinical applications of 'successful' laboratory-based bone tissue engineering strategies. To the present, grafts have been dependent on post-implant vascularization, which jeopardizes graft integration and often leads to its failure. For this reason, the development of strategies that could effectively induce the establishment of a microcirculation in the engineered constructs has become a major goal for the tissue engineering research community. This review addresses the role and importance of the development of a vascular network in bone tissue engineering and provides an overview of the most up to date research efforts to develop such a network.

\section{Introduction}

One of the most widely tested tissue engineering approach for the repair and regeneration of bone defects has been the in vitro culture of a three dimensional (3D) scaffolding

M. I. Santos, R. L. Reis

3B's Research Group - Biomaterials, Biodegradables and Biomimetics, University of Minho, Headquarters of the European Institute of Excellence on Tissue Engineering and Regenerative Medicine, AvePark, 4806-909 Taipas, Guimarães, Portugal M. I. Santos, R. L. Reis

IBB - Institute for Biotechnology and Bioengineering, PT

Government Associated Laboratory, Braga, Portugal

E-mail: marina@dep.uminho.pt

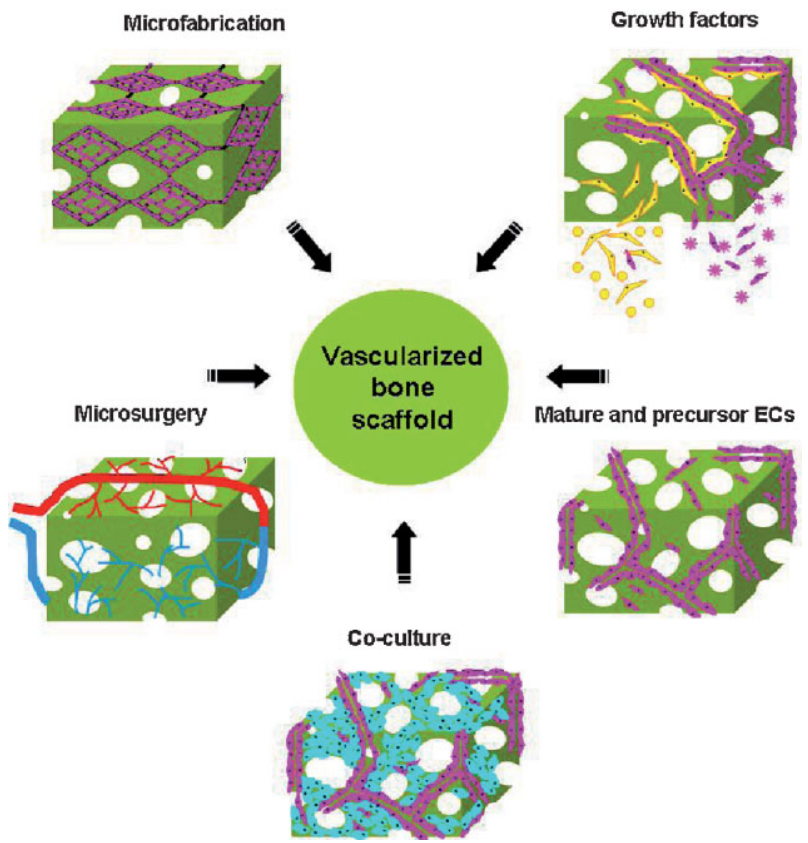

material, seeded with autologous cells, followed by implantation in the patient. Despite its enormous potential, this regenerative strategy is generally associated with a major pitfall. When the engineered tissue construct is implanted, the seeded cells will have a limited capacity to both uptake substrate molecules (oxygen, glucose, and amino acids) and to clear byproducts of metabolism $\left(\mathrm{CO}_{2}\right.$, lactate, and urea). These limitations impair cell viability to such an extent that it hinders the success of the engineered tissue. ${ }^{[1,2]}$ The lack of a functional microvasculature connected to the host blood supply has been identified as the culprit for implant failure and is currently acknowledged as the major challenge in tissue engineering. ${ }^{[3-6]}$

Bone is a metabolically active tissue supplied by an intraosseous vasculature with osteocytes distancing no 


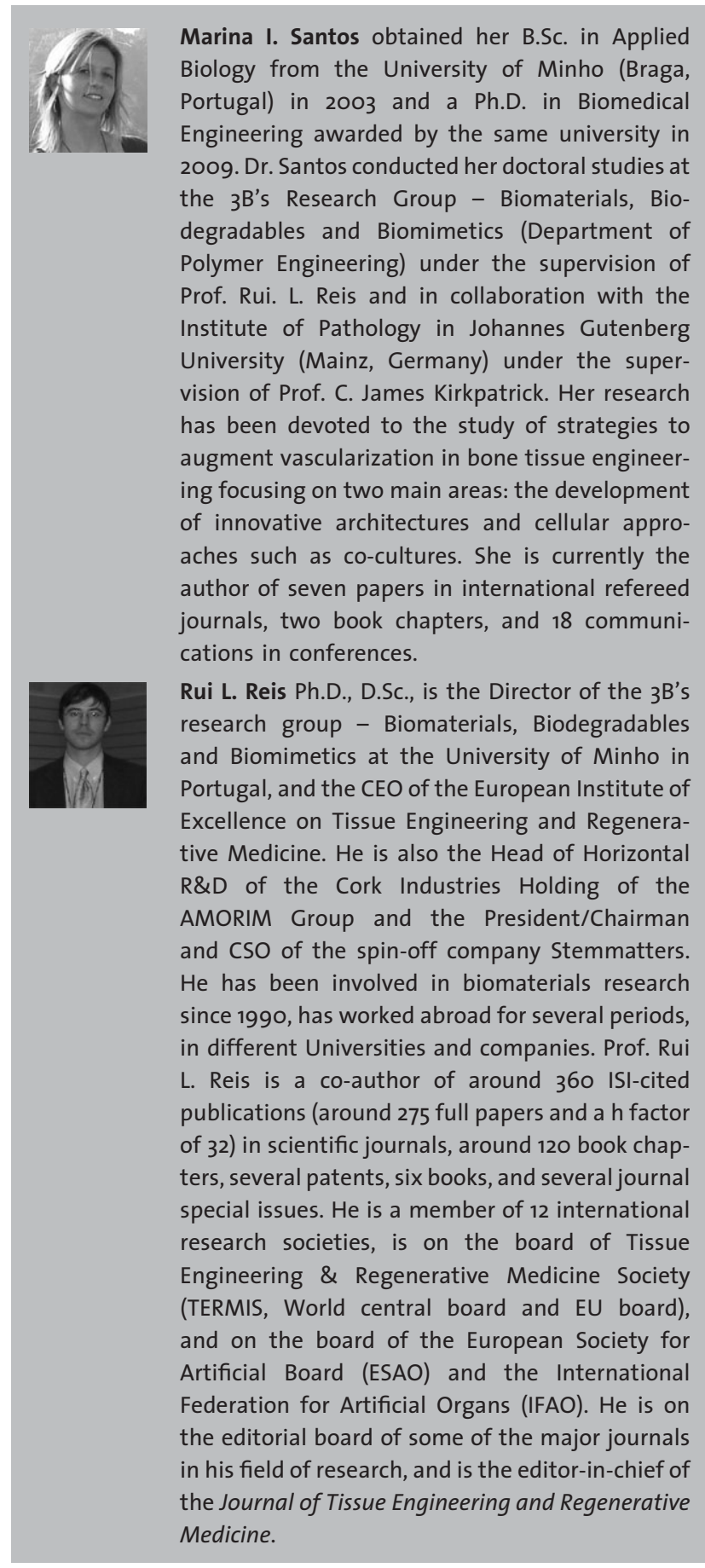

more than $100 \mu \mathrm{m}$ from an intact capillary. ${ }^{[2,7,8]}$ In the absence of a vascular supply, the transport of nutrients occurs mainly by diffusion, a transport mechanism that is only efficient over short distances or for tissues with low metabolic activity (e.g., cartilage). Theoretical modeling predicts ${ }^{[2]}$ that a centimeter thick scaffold without a vascular supply can support the metabolism of 280000 cells $\cdot \mathrm{cm}^{-3}$ without central necrosis; in native cancelous bone, this value is 1000 -fold higher. Diffusion constrains of engineered constructs are already an issue during in vitro culture, in which nutrient transport is only assured to cells on the superficial areas of the scaffold; those cells growing at a greater depth in the construct face nutrient deprivation and ultimately cell death ${ }^{[9,10]}$ From a clinical point of view this is an important aspect because resection of bone tumors or trauma originate large skeletal defects, which require large segments of implant material to be grafted. Mass transfer in a graft, defined as the in and out movement of molecules, is a phenomenon highly impaired by the thickness of the implant. ${ }^{[11]}$ In vitro delivery of nutrients to engineered constructs can be further improved with dynamic culture using bioreactor systems, ${ }^{[12,13]}$ however, this will in most cases only delay further the problem of mass transfer to the in vivo situation.

Upon graft implantation, the formation of new blood vessels from pre-existing ones, angiogenesis, will occur spontaneously. This vascular response is induced by inflammation and it is part of the wound-healing generated by the host as a response to the ischemia-reperfusion injury formed during surgery. ${ }^{[3,4,14]}$ However, capillary networks induced by inflammatory processes are relatively transient in nature and will regress within a few weeks. ${ }^{[1,15,16]}$ In addition to the capillary networks formed during wound healing, neovascularization of the scaffold occurs. However, the slow rate of infiltration of blood vessels into the scaffold $\left(<1 \mathrm{~mm} \cdot \mathrm{d}^{-1}\right)^{[4,17]}$ makes it an insufficient process to vascularize tissues of clinically relevant size. Another problem associated with the lack of vascularization is the removal of degradation products from biodegradable scaffolds. In the absence of a functional vasculature the capacity of the surrounding tissue to eliminate the degradation products derived from the implant material is very low. ${ }^{[18]}$ Consequently, there is a massive release of by-products that accumulate locally and trigger inflammatory responses. ${ }^{[19]}$

The challenge following the development of microcirculation in the engineered construct is to connect it to the hosts' systemic circulation, a phenomenon designated as inosculation or anastomose. ${ }^{[20]}$ Inosculation between the host's and construct's vasculature is not an immediate process and may take up to eight days; this may lead to ischemia and a hostile environment. ${ }^{[21]}$ Consequently, the spontaneous post-implantation neovascularization from the host is not sufficient to assure implant integration. This creates a need for new strategies to accelerate the onset of neovascularization.

The focus of the current review is on vascularization, in the context of bone tissue engineering. It aims to cover the intricate connection between vascularization and bone, starting with the development, moving through remodeling, and ending with repair. Furthermore, we will review the most recent strategies proposed to accelerate the establishment of a fully functional vascular network within bone-engineered constructs. 


\section{Intraosseous Vasculature in Bone Formation, Remodeling, and Fracture}

\section{Intramembranous and Endochondral Ossification}

Aside from assuring the nutrient transport and removal of waste products, intraosseous vasculature accomplishes other important functions that range from bone development, to remodeling and fracture repair. Depending on their origin, bone is formed by two distinct modes of ossification: by intramembranous ossification, characteristic of flat bones such as those from skull and clavicle; and by endochondral ossification, which is involved in the development of bones from load bearing joints. ${ }^{[22,23]}$ Despite the differences, the two types of ossification have as common feature: the pre-requisite of vascularization. ${ }^{\text {[24-26] }}$ In intramembranous bone formation there is an invasion of capillaries that transport mesenchymal stem cells (MSCs), which differentiate directly into osteoblasts and in turn deposit bone matrix. ${ }^{[23]}$ On the other hand, in endochondral ossification, MSCs differentiate into cartilage, which provides a template for bone morphogenesis. ${ }^{[27]}$ The hypertrophic chondrocytes in the mineralized cartilaginous matrix then secret angiogenic growth factors that promote the invasion of blood vessels, which then bring along a number of highly specialized cells that will replace the cartilage mold with bone and bone marrow. ${ }^{[23,25]}$ Vasculature also plays an important role on bone formation through the production of growth factors that control the recruitment, proliferation, differentiation, function, and/or survival of various cell including bone-forming osteoblasts and bone-resorbing osteoclasts. ${ }^{[26]}$ These bioactive factors are secreted byendothelial cells (ECs), the cell type that forms the inner lining of blood vessels. ${ }^{[28-30]}$ Therefore, angiogenesis not only precedes osteogenesis but it is also required for its occurrence. ${ }^{[31]}$ This is accomplished by a combination of factors, which include adequate oxygen tension, compression forces, nutrients, and growth factors. ${ }^{[32]}$

\section{Vascular Organization of Bone}

Adult long bone is supplied by four arterial inputs, named according to their location: nutrient artery or diaphyseal, periosteal arteries, metaphyseal arteries, and epiphyseal arteries. The nutrient artery is the largest vessel and responsible for more than $50 \%$ of total blood supply to the long bones. ${ }^{[33,34]}$ As suggested by the name, periosteal arteries supply periosteum, the membrane that covers the exterior of bones and is a rich source of stem cells, which has been tested in several regenerative strategies. ${ }^{[31,35]}$ Arteries enter the bone through the respective foramina, transverse the cortex, reach the medullary cavity, and then branch to supply the cortical and marrow microcirculations. In cortical bone the vessels branch to feed the capillaries in
Havers's and Volkmann's canals, ${ }^{[36]}$ whereas in the marrow, arterial capillaries drain into sinusoids that are low-pressure vascular channels surrounded by a single layer of fenestrated endothelium. ${ }^{[37,38]}$ Venous blood is drained to the venous central sinus that runs along the middle of the diaphysis and leaves the bone through veins that accompany arteries. ${ }^{[34,36]}$

\section{Bone Remodeling}

Cortical and cancelous bone undergo ceaseless remodeling starting in the $6^{\text {th }}$ week of gestation and continuing throughout adulthood. ${ }^{[8,36]}$ Bone remodeling comprises two phases, resorption of pre-existing bone tissue by the osteoclasts, followed by de novo bone formation by the osteoblasts. ${ }^{[39,40]}$ Osteoblasts have a tight control on the osteoclastic activity, thus balancing resorption and bone deposition. When metabolically active, osteoblasts secret osteoprotegerin, an inhibitor of osteoclast activity, whereas the mature osteoblasts loose the ability to produce this molecule and render bone vulnerable to osteoclast resorption. ${ }^{[41]}$ Blood vessels direct osteoclast precursors to specific areas of bone, i.e., to bone multicellular units (BMU). ${ }^{[22]}$ These are small compartments composed by osteoblasts, osteoclasts, and blood vessels where remodeling takes place. ${ }^{[42]}$ In BMU resorption is initiated when the receptor activator for nuclear factor kappa B ligand (RANKL), secreted by osteoblast, binds to RANK receptors on the osteoclast cell membrane. ${ }^{[41,43]}$ Meanwhile, bone vessels start the second phase of the process by trafficking osteoprogenitor cells into BMU for the deposition of new bone. ${ }^{[40]}$ The invading vasculature, therefore, serves as both a reservoir and conduit for the recruitment of essential cell types involved in bone resorption and deposition, regulates the functional activities of such cells, and provides key signals necessary for bone morphogenesis. ${ }^{[32]}$ In summary, alterations of the microvascular supply network will ultimately affect the tightly regulated resorption sequence to result in a decrease in bone formation, regeneration, and repair. ${ }^{[22]}$

\section{Fracture Repair}

One of the hallmarks of bone is, upon injury, its capacity to truly regenerate, ${ }^{[14]}$ in contrast to soft tissue that heals by forming scar tissue. ${ }^{[27]}$ Fracture repair is a complex regenerative mechanism as evidenced by the distinguishable processes that it involves, such as the immediate response to injury, intramembranous bone formation, endochondral bone formation, and bone remodeling. ${ }^{[4]}$ When bone is injured not only skeletal integrity is compromised at the fracture site, but intraosseous vasculature is clearly disrupted. ${ }^{[22]}$ Firstly a hematoma is formed; secondly, the fracture milieu becomes hypoxic because of the disruption of oxygen supply. Hypoxia is an important 
physiological signal in bone repair because it regulates the production of key modulators by osteoblasts that influence EC proliferation, ${ }^{[32]}$ direct cellular differentiation, ${ }^{[45]}$ and induce ECs to secret osteogenic growth factors. ${ }^{[46,47]}$ In the hematoma phase, the first out of four overlapping phases that characterize bone repair, a normal healing response is triggered. ${ }^{[48,49]}$ The inflammatory response and the hypoxic environment are associated with the release of several growth factors and cytokines that trigger EC migration and the formation of new capillaries. ${ }^{[26,48]}$ In fact, the reconstruction of intraosseous circulation is one of the earliest events during bone repair. ${ }^{[49,50]}$ Meanwhile, the hypoxic microenvironment supports the differentiation of MSCs into chondrocytes that stabilize the fracture by cartilage formation, known as an internal callus. ${ }^{[14]}$ The periosteum then directly undergoes intramembranous bone formation, which leads to the formation of an external callus. In the next phase, hard callus formation, the internal callus becomes mineralized and forms a hard callus of woven bone. Finally, in the remodeling phase, the callus is replaced by lamellar bone. ${ }^{[48]}$

External factors such as the biomechanical environment also influence the bone regenerative process by affecting angiogenesis and consequently cell differentiation. ${ }^{\left[{ }^{[51,52]}\right.}$ In a fixated fracture the vascular network is rapidly reestablished and healing occurs mainly by intramembranous ossification. ${ }^{[51,52]}$ Conversely, in an unstable mechanical environment the spreading capillaries are disrupted and the hypoxic environment promotes the differentiation of chondrocytes that stabilize the fracture by cartilage formation. ${ }^{[14]}$ Lack of angiogenesis has been pointed out $^{[51]}$ as one of the main reasons for non-healing bone. For instance, using a rat distraction osteogenesis model, Fang et al. ${ }^{[53]}$ have shown that the administration of an anti-angiogenic drug prevented normal osteogenesis, which resulted in a fibrous non-union.

\section{Heterotypic Communication between Osteoblasts and Endothelial Cells}

Considering the intricate connection between angiogenesis and osteogenesis, it is not surprising that communication between osteoblasts and ECs is one of the most important cellular interactions that orchestrate bone formation. ${ }^{[32,54]}$ The cross-talk between osteoblasts and ECs occurs at two levels: 1) by indirect cell contact, ${ }^{[55,56]}$ through the release of soluble factors with paracrine and autocrine action, and 2) by direct cell-cell contact, ${ }^{[57]}$ mediated by proteins at gap junctions. One of the most studied growth factors is vascular endothelial growth factor $(\mathrm{VEGF})^{[49,58,59]}$, a potent and specific angiogenic cytokine produced at the fracture site by numerous cell types, including osteoblasts. Besides being an EC-specific mitogen, VEGF also induces increased vascular permeability and monocyte migration through endothelial layers. ${ }^{[60]}$ The action of VEGF is not limited to ECs, and there are some studies reporting that osteoblasts also respond to members of the VEGF family. ${ }^{[61-63]}$ A recent study ${ }^{[24]}$ has shed some light on the cellular and molecular mechanisms responsible for controlling VEGF-dependent osteoblast-ECs crosstalk by confirming that VEGF is released predominantly by human osteoblasts and its primary action is by ECs. Another angiogenic growth factor, fibroblast growth factor (FGF), is also produced by osteoblasts among other cell types. ${ }^{[64,65]}$ FGF functions as a paracrine factor to stimulate EC proliferation and migration, ${ }^{[65]}$ and as an autocrine factor to induce the proliferation and differentiation of osteoblasts. ${ }^{[22]}$ Furthermore, FGF-2 exerts its angiogenic effect indirectly by modulating VEGF expression through its action over osteoblasts. $^{[66]}$ Once the crosstalk between ECs and osteoblasts is bidirectional, ECs also secret numerous regulatory molecules that exert major effects in controlling the differentiation and activity of bone-forming cells. ${ }^{[32]}$ Bone morphogenic protein-2 (BMP-2) and endothelin-1 (ET-1) are two of the growth factors produced by ECs that promote osteoblastic proliferation and differentiation. ${ }^{\text {[67-69] }}$ In addition, platelet-derived growth factor BB (PDGF-BB), released at the fracture site by several cell types that include ECs, has a mitogenic and chemotactic effect over osteoblasts. ${ }^{[70,71]}$ Osteogenic growth factors produced by ECs (BMP-2, PDGF-BB) and by osteoblasts (insulin-like growth factor, IGF, and transforming growth factor, TGF) also have an angiogenic effect by inducing VEGF mRNA expression in osteoblasts. ${ }^{[70,72-74]}$ Veillette and Schroeder ${ }^{[75]}$ proposed an inhibitory role of ET-1 on VEGF synthesis in osteoblastic cells as a feedback mechanism in the temporal and spatial coupling of angiogenesis to bone formation and resorption.

External factors such as the hypoxic microenvironment of fracture healing stimulate the expression of a variety of cytokines from inflammatory cells, ECs, osteoblasts, and fibroblasts. ${ }^{[76]}$ ECs and osteoblasts respond to hypoxia by upregulating the expression of numerous osteogenic factors (ET-1, PDGF-BB, BMP-2, IGF-II, and TGF- $\beta 1$ ) and of the angiogenic growth factor VEGF. ${ }^{[68,76-80]}$ The mechanism underlying the response of cells to the hypoxic microenvironment is primarily mediated through genes whose expression contain a hypoxia-inducible factor-1 (HIF-1) binding site. ${ }^{[81,82]}$ Nevertheless, it has been reported $^{[76,79,83]}$ that this environment of low oxygen tension has no effect on the expression of growth factors such as FGF-2 and members of IGF and TGF families.

The fact that hypoxia is a driving factor for the creation of a growth factor rich milieu inspired researchers to test its potential benefits in engineered tissues. Several studies have addressed oxygen tension as an important variable in optimizing in vitro conditions for stem differentiation, ${ }^{\text {[84-87] }}$ while others ${ }^{[45]}$ have hypothesized that adapting the graft 
to hypoxia prior to engraftment might induce angiogenesis after implantation. It is obvious that in order to avoid the noxious effects of low oxygen tension, culture conditions must be well defined. On the one hand, $48 \mathrm{~h}$ of culture do not have a significant effect on cell death, ${ }^{[88]}$ on the other hand, long-term cultures will have a negative effect on bone formation partly because of decreased osteoblast proliferation. $^{[89]}$

\section{Strategies to Increment Vascularization}

In order to accelerate the establishment of a functional vascular network in bone engineered tissues several strategies have been proposed (Figure 1). The following sections will review the main approaches, their principles, outcomes, and limitations.

\section{Scaffold Architecture}

The resection of tumors. ${ }^{[90,91]}$ congenital deficiency, trauma, or infection ${ }^{[92]}$ are the main pathologies responsible for the loss of large bone segments. Engineered bone must assure the mechanical stability of the osseous defect, while simultaneously stimulating the healing capacity of the tissue. The vast majority of bone regeneration strategies have been centered on the scaffold material; however, within the last few years a conceptual shift has been taking place in the development of scaffolds for bone engineering, from a support role for bone-forming cells, to a scaffold that

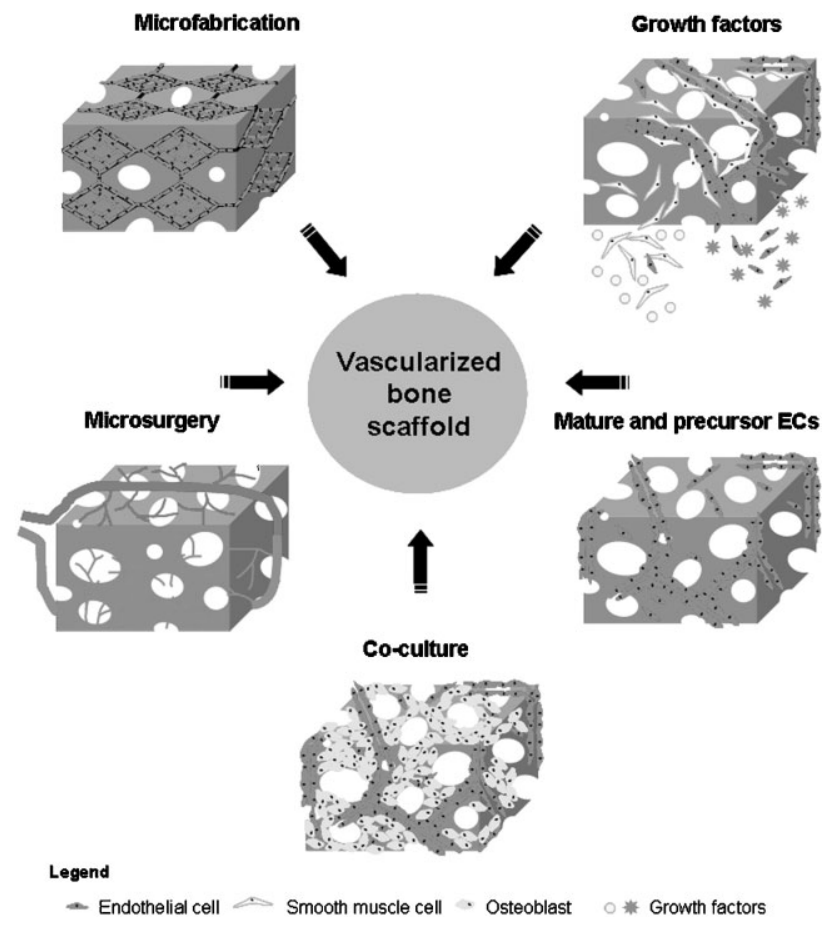

Figure 1. Illustration of the main five approaches to induce vascularization in a bone construct. homes a vascular network. Regarding the bulk properties of a scaffolding material, porosity has been one of the most discussed issues ${ }^{[93-95]}$ but with a focus mainly on osteoblast proliferation, matrix deposition, and calcification rather than the in penetration of vasculature. Recent work from Narayan and Venkatraman ${ }^{[96]}$ evaluated the effect of pore size and interpore distance over ECs growth on 3D polymeric scaffolds and found that cell growth was enhanced by a smaller pore size $(5-20 \mu \mathrm{m})$ and lower interpore distance. A similar behavior was also reported for osteoblasts, where lower porosity stimulates osteogenesis by suppressing cell proliferation and forcing cell aggregation in vitro. ${ }^{[95]}$ However, the in vivo scenario is completely different and a higher porosity and pore size result in greater bone in-growth and vascularization. ${ }^{\text {[95,97] }}$ This is explained by the fact that when implanted, scaffolds with smaller pores tend to be hypoxic, favoring chondrogenesis, whereas in constructs with larger pores the higher oxygen tension promotes the differentiation of MSCs into osteoblast lineage, favoring osteogenesis.

\section{Hierarchical Structures}

The design and architecture of the scaffold are two other features critical for the formation of a vascular network. One example of an innovative architecture is the nano/ micro fiber-combined scaffold (Figure 2a). ${ }^{[98]}$ This scaffold made from a blend of starch with polycaprolactone $(\mathrm{SPCL})^{[13,94,99-101]}$ combines in the same structure microand nanofibers. Microfibers obtained by fiber bonding were combined with nanofibers produced by electrospinning in a single structure. In this way the scaffold material is capable of simultaneously providing the mechanical support for bone repair and mimicking the physical structure of the extracellular matrix (ECM). As will be described later in greater detail, strategies that include seeding ECs on
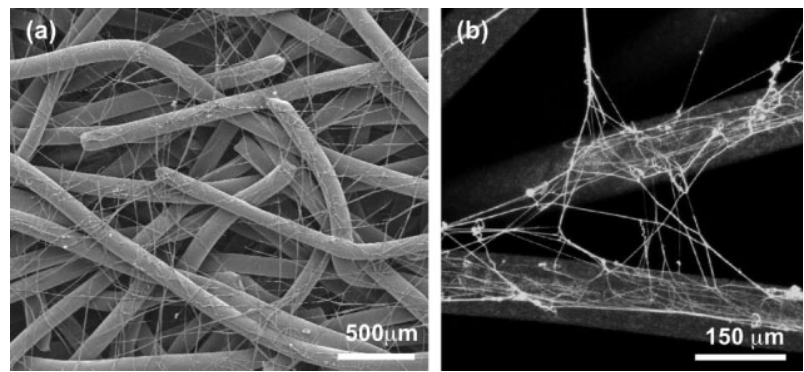

Figure 2. The architecture of nano/micro combined structures. These scaffolds comprise two structures: a micro-fiber mesh to give the mechanical support required during bone repair and a nano-network that mimics the ECM that can be made from a) SPCL or b) collage I. a) Scanning electron micrograph (SEM) of the SPCL nano/micro fiber-combined scaffold. b) Confocal laser scanning micrograph (CLSM) of a collagen-nano and SPCL-micro fibercombined scaffold stained with type I collagen where nano-fibers are depicted in green fluorescence. 
biomaterials and promoting their adhesion, migration, and functionality might be a solution for the formation of vascularized bone. Therefore, the nanonetwork that resembles the ECM physical structure on SPCL nano/micro fiber-combined scaffolds was designed with the aim to promote EC migration, and to establish a vascular network. Under pro-angiogenic conditions in vitro, this nanonetwork provided the structural and organizational stability for the migration and organization of ECs into capillary-like structures. ${ }^{[102]}$ The architecture of nano/micro-fiber-combined scaffolds elicited and guided the 3D distribution of ECs without compromising the structural requirements of a scaffold for bone regeneration. Our group further tested the combination of these structures and developed a scaffold that comprised type I collagen nanofibers on a SPCL fibermesh structure (Figure 2b). ${ }^{[103]}$ Besides being one of the main constituents of ECM, type I collagen provides chemotactic and haptotactic signals to migrating ECs. ${ }^{[104]}$ Thus, by providing both physical and chemical cues to enhance EC motility, the collagen-nano and SPCL-micro fiber-combined structure might lead to an increase of angiogenic activity. Alternatively, Yang et al. ${ }^{[105]}$ used extrusion free forming, a rapid prototyping technique to fabricate ceramic scaffolds with three distinct structure levels: submicrometer pores, aimed to enhance cell/surface interactions, pores of tens of micrometers to encourage bone ingrowth, and corridors (hundreds of micrometers) for vascularization. Another rather interesting concept has been recently introduced by Bellan et al., ${ }^{[106]}$ who promoted the construction of a vascular network using sacrificial sugar structures. Briefly, macro- and microfibers made of sugar were produced by melt-spinning and included in a polymeric matrix, such as poly(dimethylsiloxane) (PDMS). The structure is then soaked in water and the sugar-fibers solubilized, leaving in the polymeric matrix macrochannels that can be attached to a blood supply and microchannels with diameters close to that of capillaries.

\section{Microfabrication of Networks with Vascular Geometry}

Another interesting concept is the inclusion of a network with a vascular geometry in a biocompatible polymer. This is achieved by microfabrication techniques that comprise a

Table 1. Microfabrication techniques used to engineer structures with vascular geometry; compiled from ref. ${ }^{[108,110-112,200,201]}$

\begin{tabular}{|c|c|c|c|c|}
\hline Microfabricated Structure & Substrate $^{a)}$ & Processing methodology & In vitro & Ref. \\
\hline $\begin{array}{l}\text { Network with } \\
\text { vascular geometry }\end{array}$ & PGS & Lithography & $\begin{array}{l}\text { Lumens endothelialized } \\
\text { under flow } \\
\text { perfusion after } 14 \mathrm{~d}\end{array}$ & [110] \\
\hline $\begin{array}{l}\text { Network with } \\
\text { vascular geometry }\end{array}$ & PDMS & $\begin{array}{c}\text { Silicon microfabrication and } \\
\text { polymer replica molding }\end{array}$ & $\begin{array}{l}\text { HMEC-1 reached } \\
\text { confluency after } 4 \mathrm{~d}\end{array}$ & [108] \\
\hline $\begin{array}{l}\text { Aligned topographical } \\
\text { microridges and } \\
\text { microgrooves }\end{array}$ & $\begin{array}{l}\text { UA grafted } \\
\text { with PIPAAm }\end{array}$ & $\begin{array}{l}\text { Photolithography and } \\
\text { soft lithography }\end{array}$ & $\begin{array}{l}\text { ECs reach confluency } \\
\text { within } 7 \mathrm{~d} \text { of } \\
\text { culture and at } \\
\text { longer ( } 2-3 \text { weeks) } \\
\text { form capillary-like } \\
\text { tube formation }\end{array}$ & [111] \\
\hline
\end{tabular}

\begin{tabular}{|c|c|c|c|}
\hline $\begin{array}{l}\text { Microchannel } \\
\text { network }\end{array}$ & PC and PLGA & $\begin{array}{l}\text { Stainless steel eletroforming and } \\
\text { silicon electroforming }\end{array}$ & $\begin{array}{l}\text { Bovine ECs dynamically } \\
\text { seeded reached } \\
\text { near-confluency after } 3 \mathrm{~d}\end{array}$ \\
\hline $\begin{array}{l}\text { Microchannel } \\
\text { network }\end{array}$ & PDMS & Laser direct writing & n.a. \\
\hline $\begin{array}{l}\text { Microcapillary } \\
\text { structure }\end{array}$ & SU8 & Two-photon polymerization & n.a. \\
\hline
\end{tabular}
epoxy-based polymer (photosensitive), PC: Polycarbonate. 
full range of processes and tools originally developed for applications in the microelectronics, automotive, aerospace, and defense fields. ${ }^{[107]}$ Photolithography, a process based on semiconductor wafer technologies, has been attracting attention. This method is a two-step process where a mold is first produced, generally made of silica, with an imprinted pattern. By replica-molding, the pattern is then printed in a biocompatible polymer where the cells will be cultured. ${ }^{[108]}$ The microfabricated pattern can range from aligned microgrooves to a network with vascular geometry, which can be incorporated into a biodegradable or non-biodegradable material (Table 1). In order to achieve the best hydrodynamic performance the imprinted network should be made up of multi branches with no more than two vertical nodes in each individual branch. ${ }^{[109]}$ Fidkowski et al. ${ }^{[110]}$ engineered a microvascular network made of poly(glycerol sebacate) (PGS), a biodegradable and functional in vivo elastomer with mechanical properties similar to veins. To this end, a capillary network pattern was imprinted in PGS using microfabricated silicon wafers as molds. By seeding the imprinted capillary networks with ECs and perfusing them with culture medium it was then possible to obtain a bioengineered microvascular network in vitro. Moreover, by combining fabrication with the principle of thermoresponsive surfaces it is possible to take the fabrication of artificial networks to a whole new level. By imprinting the capillary pattern in a thermoresponsive polymer it is possible to harvest an EC tubular network that can then be used in the fabrication of 3D vascularized tissue grafts. ${ }^{[111]}$ Unfortunately, a drawback of photolithography is its inability to create 3D architectures. Recently, a novel computer-aided design/computer-aided manufacturing (CAD/CAM) technology named two-photon polymerization (2PP) has emerged that allows the fabrication of any computer-designed 3D structure with a structural resolution down to $100 \mathrm{~nm}$ from a photosensitive polymer material. ${ }^{[112]} 2 \mathrm{PP}$ was applied to a photosensitive polymer to successfully produce a microstructure with the shape of microcapillaries. ${ }^{[113]}$ The flexibility of this technology and the ability to precisely define a 3D construct geometry holds a great potential to address issues associated with the establishment of an intrinsic microcapillary network. Another CAD/CAM technique used for scaffold production is rapid prototyping. ${ }^{[90,114]}$ Moroni et al. ${ }^{[115]}$ developed 3D fiber deposition, a rapid prototyping tool to create 3D scaffolds with a hollow fiber architecture. Because of their hollow structure these fibers can potentially provide the physical support within the 3D matrix for the formation of a compartmentalized vasculature.

A general remark regarding microfabrication is that these technologies are being mainly applied to the establishment of a complex branching vascular tree in soft organs. A hard tissue such as bone has an increased level of complexity, which demands microfabrication methods to be adapted in order to simultaneously address design and mechanical issues. For an excellent review about microfabrication in the context of tissue engineering please refer to Borenstein et al. ${ }^{[107]}$

\section{Angiogenic Growth Factors}

Because of the close association between angiogenesis and osteogenesis, angiogenic growth factors are implicated in neovascularization and in endochondral ossification, making them important therapeutic agents for bone regeneration. ${ }^{[59,116]}$ For instance, VEGF, the main angiogenic growth factor involved in bone healing, has an important role in bone repair by promoting angiogenesis and by stimulating major skeletal cell populations, chondrocytes, osteoblasts, and osteoclasts. ${ }^{[117]}$ Current approaches to therapeutic angiogenesis focus on localized and sustained delivery of growth factors ${ }^{[118,119]}$ rather than on local and systemic bolus injection. ${ }^{[120]}$ Delivery systems permit prolonged exposure of regenerating tissue to low and localized doses of angiogenic factors ${ }^{[118,119]}$ and are superior over bolus injection, characterized by the lack of control over the growth factors' availability. A great variety of natural, ${ }^{[121-127]}$ synthetic, ${ }^{[128]}$ and composite materials ${ }^{[129,130]}$ have been used as delivery matrices for angiogenic growth factors. The localized and sustained delivery of VEGF from macroporous biomineralized poly(lactide-co-glycolide) (PLGA) led to simultaneous regeneration of both vascular and bone tissue in a cranium critical defect. ${ }^{[130]}$ A particular case where angiogenic therapy can be applied but where care should be exerted is in defects that result from the resection of carcinomas that failed to be eliminated with radiation therapy. ${ }^{\left[{ }^{92]}\right.}$ In these cases not only is there a large segmental loss of bone but the regenerative capacity of the adjacent tissue is also impaired because of vasculature damage by radiation treatment. ${ }^{[92,131]}$ The work of Kaigler at el. ${ }^{[128]}$ addressed this problem by delivering VEGF from PLGA scaffolds in irradiated osseous defects. Although this was revealed to be an effective strategy to increase neovascularization and bone regeneration, the use of growth factors in cancer walks the tenuous line that separates the therapeutic and pathological effects of angiogenic growth factors. Other drawbacks of VEGF delivery is its inherent instability in vivo ${ }^{[4]}$ and the required high doses of recombinant protein that escalate the therapy cost. ${ }^{[132]}$

The advances in molecular biology and drug delivery permitted the localized delivery of the gene that codes for the angiogenic molecule of interest. For instance, Tarkka and collaborators ${ }^{[117]}$ have used a first-generation adenoviral vector to deliver VEGF in a mouse femur defect and reported that gene transfer induced angiogenesis, and improved bone healing and bone mineral content. Another way to promote fracture healing by means of VEGF gene 
transfer consists in transfecting cells with the gene of interest and thus using them as vectors. When fibroblasts transfected with VEGF were applied to bone defects complete bridging of new bone was observed, whereas in the control (fibroblasts alone) the defects were fibrous and sparsely ossified. ${ }^{[133]}$

One of the most critical and important aspects when designing an angiogenic therapy is the dose of angiogenic growth factor delivered. ${ }^{[119,134]}$ For instance, blood vessels formed by exposure to high doses of VEGF tend to be malformed and leaky. ${ }^{[119]}$ In addition, one can not disregard that angiogenesis is associated to several pathologic processes such as tumor development, atheroscleosis, and proliferative retinopathies, so there is the risk that a treatment with an angiogenic growth factor might exacerbate these processes. ${ }^{[135]}$ Experiments performed by Davies et al. ${ }^{[134]}$ shed some more light on the effect of the continued delivery of VEGF concentrations on scaffold vascularization. They reported that the administration of $150 \mathrm{ng}$ a day led to a constant increase in vascularization, even after the cessation of delivery, whereas a 10 times higher concentration induced transient vessel growth into the porous scaffold.

Angiogenesis can also be triggered using specific peptide sequences derived from adhesion proteins ${ }^{[136]}$ or from molecules of the extracellular matrix. ${ }^{[137,138]}$ The advantage of these short peptide sequences over the parent protein is the higher control over the elicited response and the possibility to be easily grafted on a substrate. ${ }^{[139]}$ Hamada and co-authors reported that the peptide sequence Ser-ValVal-Tyr-Gly-Leu-Arg (SWYGLR) derived from osteopontin exhibited potent angiogenic activity in vitro and in vivo. ${ }^{[137,140]}$ When grafts made of a carbonate-collagen sponge that contained the SWYGLR motif were implanted in a murine bone defect, prominent angiogenesis inside the graft was observed just one week after the implantation. ${ }^{[141]}$ Peptide sequences can also allow cell-type selectivity. This is the particular case of the tetrapeptide Arg-Glu-Asp-Val (REDV), a domain derived from the adhesive protein fibronectin. ${ }^{[136,142]}$ It was shown that substrates that contained covalently immobilized REDV peptides selectively supported the attachment and spread of human ECs over that of other cell types. ${ }^{[136]}$

Recently other molecules with dual action have also been tested. Sphingosine 1-phosphate (S1P) is a bioactive phospholipid that affects the proliferation and migration of ECs, smooth muscle cells (SMCs), and osteoblast-like cells. Because of its multiple cellular targets, S1P is an attractive molecule for bone repair and Sefcik et al. ${ }^{[143]}$ have evaluated the sustained release of S1P-loaded microsphere-based scaffolds in a critical-size cranial defect. Their findings have shown that the sustained delivery of S1P significantly stimulated new bone formation and increased vasculature in the defect site.
Considering that angiogenesis is a multifactorial process that involves the interplay of several factors, a way to induce the formation of mature and stable blood vessels includes the administration of multiple growth factors. Kilian et al. ${ }^{[144,145]}$ have tested the potential of enrichment with a non-defined cocktail mixture of growth factors isolated from the platelet fraction aimed to stimulate the formation of new blood vessels in osseous defects. Using nanoparticulate hydroxyapatite (HA), neovasculature was formed in the defects independently of the delivery of platelet growth factors. The low affinity of cytokines to HA might be a reason for the lack of angiogenic effect of this cocktail of growth factors. On the other hand, other work $^{[146]}$ has tested the combined addition of both FGF-2 and VEGF to a collagen/heparin scaffold and has reported the establishment of an early mature vasculature. Growth factors with angiogenic properties can also be part of other multifactorial delivery systems. For instance, the concerted delivery of VEGF, BMP-4, and human bone marrow mesenchymal stem cells (hBMSCs) from biodegradable scaffolds proved to be more effective at promoting bone formation when compared with any single or combination of two factors. ${ }^{\text {[147] }}$

However, the real turning point in delivery systems from a single growth factor to a dual growth factor delivery technology came with the landmark paper from Richardson et al. ${ }^{[148]}$ They reported a polymeric system that allows the delivery of two or more growth factors with controlled dose and rate of delivery. With the coordinated spatial and temporal presentation of VEGF and PDGF it was possible to obtain a rapid and mature vascular structure. ${ }^{[148]}$ PDGF is the key factor for vessel stabilization because it is responsible for the recruitment of SMCs and pericytes. ${ }^{[118,148]}$ In summary, an effective and safe angiogenic therapy is not only dependent on the right combination of growth factors delivered but also on a temporal and dose controlled release.

\section{Mature and Precursor Endothelial Cells}

Regardless of the approach adopted to accelerate vascularization, all of the strategies will, directly or indirectly, include ECs. Hence, in light of the critical role of ECs in the angiogenic process, a necessary step to evaluate and properly predict the vascularization potential of biomaterials is to assess the interaction of ECs with the respective substrate. ${ }^{[149-151]}$ A great number of works have examined different aspects of ECs such as cell attachment, viability, growth, and phenotypic/genotypic expression on different bone substitutes: collagen, ${ }^{[152]}$ silk fibroin, ${ }^{[153]}$ polyethersulfone,${ }^{[151]}$ polycaprolactone (PCL), ${ }^{[154]}$ and PLGA. ${ }^{[149]}$ SPCL, a fiber-mesh scaffold and a material proposed by our group for bone regeneration, ${ }^{[13,94,99-101]}$ was also revealed to be compatible and a rather good substrate for ECs. ${ }^{[150]}$ 
However, similar to what was observed in a large number of other polymeric substrates, ${ }^{[155-157]}$ in order to sustain EC adhesion and endothelialization the surface of the SPCL fiber-mesh scaffolds required a pre-coating with an adhesive protein. ${ }^{[150]}$ Protein coating has several drawbacks, namely the difficulty to control it and its stability over time. ${ }^{[136]}$ Methods such as plasma treatment, ${ }^{[158]} \mathrm{UV}$ radiation, ${ }^{[159]}$ chemical treatment, ${ }^{[160]}$ and grafting with bioactive molecules, ${ }^{[136]}$ have been employed to surfacemodify polymers towards improving biocompatibility for ECs. In the case of a SPCL fiber-mesh scaffold, to render the surface compatible for ECs without the need of protein precoating, the material was modified with an Ar plasma. The Ar-modified scaffolds had a performance comparable with the fibronectin-coated substrate, i.e., the proliferation profile of cultured ECs was similar and expression of the endothelial markers was the same. Further investigation revealed that the treatment by Ar plasma changed the chemical and physical properties of the substrate and consequently changed the adsorption pattern of the adhesive protein vitronectin. ${ }^{[158]}$

Alternatively, ECs can be used to engineer a vascular network, in an approach based on the principle that transplanted ECs will interact with host ECs and vasculature, thus establishing a vascular supply much faster. The first line of evidence of a constructed vascularization as a result of EC transplantation came from the work of Holder et al. ${ }^{[161]}$ Poly(glycolic acid) (PGA) porous matrices seeded with aortic ECs have shown organized/unorganized ECs within the matrix, and increased numbers of capillaries and lymphaticlike structures relative to the control (SMCs and skeletal muscle cells). The feasibility of engineering a microvascular network in vivo was later confirmed with ECs derived from the macro- and microvasculatures. ${ }^{[162,163]}$ However, Koike et al. ${ }^{[6]}$ have shown that in order to obtain stable and durable vascular networks ECs require co-implantation with perivascular cells. These findings highlight that although mature ECs have the required proliferative and angiogenic activity to create vascular networks in vivo, the cooperation between ECs and perivascular cells is fundamental for vascular maturation.

Mature ECs can be isolated from a great variety of sources such as the umbilical cord, skin, fat tissue, and saphenous vein. However, the low availability and proliferation capacity are the major drawbacks of using these cells. ${ }^{[164,165]}$ There are also other problems associated with mature ECs. Firstly, the senescent state of ECs on larger vessels that can lead to the existence of defective signaling pathways and thus decrease the ability to properly respond to angiogenic growth factors. ${ }^{[4,30]}$ Secondly, mature ECs display remarkable phenotypic and genotypic heterogeneity in different tissues, and these differences might generate different responses depending on the tissue from where the cells were isolated. ${ }^{[29,30,166]}$
An alternative source of autologous ECs to support proangiogenic therapies in tissue engineering are endothelial progenitor cells (EPCs). These cells, identified through the expression of three cell markers (CD133, CD34, and vascular endothelial growth factor receptor 2, VEGFR2) are present in bone marrow, fat tissue, and peripheral blood, and are able to differentiate into mature ECs and participate in both angiogenesis and vasculogenesis. ${ }^{[167,168]}$ EPCs occur in a low number, but when expanded in culture can undergo more than 1000 population doublings, in sharp contrast to mature ECs that senesce after 30 population doublings. ${ }^{[169]}$

EPCs are a heterogeneous population composed by two cell sub-populations: early-EPCs ${ }^{[170]}$ and late-EPCs. ${ }^{[170,171]}$ As suggested by their name, early-EPCs are the first to appear in culture generally within 4-7 d, share some endothelial but also monocytic characteristics, and exhibit a restricted capacity of expansion. ${ }^{[170]}$ In contrast, late-EPCs also known as blood outgrowth ECs (OECs) develop after 2-3 weeks of culture, and exhibit a cobblestone-like morphology and long term proliferative potential. ${ }^{[170,171]}$ Regarding the differences and relevance of the different populations of EPCs on vascularization, the work from Yoon et al. ${ }^{[172]}$ highlights the synergy between EPC populations during neovascularization. In this work it was shown that the injection of early EPCS $\left(\mathrm{CD} 14^{+}\right)$and OECs resulted in superior neovascularization in vivo relative to any singlecell-type transplantation. It was suggested that this synergy between EPC populations might be a result of different contributions: early EPCs may contribute to neovascularization by secretion of cytokines and matrix metalloproteinase-8 (MMP-8), whereas OECs participate by providing building blocks and secreting MMP-2.

The phenotypic stability in culture that characterizes $\mathrm{OECs}^{[171]}$ has also been demonstrated in 3D matrices. OECs have been used in combination with fibroin silk fiber meshes for application in tissue engineering and the results have shown endothelialization of fibroin silk fiber meshes, while maintaining their endothelial characteristics and functions. ${ }^{[173]}$ Furthermore, when embedded in a woundhealing matrix, OECs migrated from the fibroin scaffolds and formed a microvessel-like network in vitro.

EPCs have already been successfully applied in the treatment of fracture healing. Matsumoto et al. ${ }^{[174]}$ demonstrated that transplantation of EPCs can be a successful strategy for the treatment of delayed fracture unions. Briefly, EPCs were systemically transplanted and recruited to the osseous fracture by factors present in the healing environment. Once within the fracture site, the transplanted cells enhanced vasculogenesis/angiogenesis and osteogenesis, which led to fracture healing. However, in order to avoid large systemic doses of EPCs and potential side effects, ${ }^{[175]}$ later on the same group refined the strategy ${ }^{[176]}$ For that, EPCs were seeded in the femoral non-union site and mobilized by local delivery of granu- 
locyte colony stimulating factor, hence promoting fracture union.

Similarly, as reported for mature cells, for EPCs to form stable and long-lasting microcapillary structures, the construct requires a perivascular component. ${ }^{[177,178]}$ For instance, it has been found that seeding EPCs in poly(glycolic acid)/poly(L-lactic acid) (PGA-PLLA) preserved the endothelial phenotype but the formation of microvessels in vitro was only observed when SMCs were added to the culture $^{[169]}$ In the same research line, the formation of functional microvascular beds in immunodeficient mice by co-implantation of EPCs and mesenchymal progenitor cells isolated from blood and bone marrow, respectively, were reported. ${ }^{[179]}$

\section{Co-Culture Systems}

Bone is a complex tissue and this is well present in the multitude of cell populations that compose it. Hence, it is expected that the co-culture of heterogeneous cell types will recreate more closely the in vivo environment than singlecell cultures. ${ }^{[154,180]}$ As previously described, one of the most important heterotypic cross-talks in fracture is the one between ECs and osteoblasts. Many researchers ${ }^{[181-183]}$ have tested this relationship and have designed strategies to regenerate a vascularized bone construct based on the simultaneous culture of these two cell types. Co-cultures may be applicable to a prevascularization strategy for biomaterials prior to implantation ${ }^{[183]}$ or to a post-

Table 2. Co-culture systems for vascularization of bone constructs; compiled from the Ref. ${ }^{[102,154,181-186,191,202,203]}$

\begin{tabular}{|c|c|c|c|c|}
\hline $\begin{array}{l}\text { Components of } \\
\text { co-culture system }\end{array}$ & & Substrate $^{b)}$ & In vivo & Ref. \\
\hline HUVEC & hOBs & Tutobone ${ }^{\circledR}$ & $\begin{array}{l}\text { Recruitment of mural } \\
\text { cells and anastomose } \\
\text { with host vasculature }\end{array}$ & [191] \\
\hline HUVEC & hOBs & Polyurethane scaffolds & n.a. & [184] \\
\hline Cell line & Bone marrow & PCL scaffold & n.a. & [154] \\
\hline HBMEC-60 & fibroblasts & & & \\
\hline HDMEC & hOBs or MG-63 & Several 3D bone materials & n.a. & [183] \\
\hline HDMEC & hOBs & SPCL fiber-mesh scaffolds & n.a. & [102] \\
\hline HUVEC & hOBs & Collagen gel & n.a. & [202] \\
\hline OECs & hOBs or MG-63 & Scaffold-free approach & n.a. & [182] \\
\hline HUVEC & hMSCs & Scaffold-free approach & $\begin{array}{l}\text { Limited anastomose with } \\
\text { host vasculature }\end{array}$ & [181] \\
\hline $\begin{array}{l}\text { Kidney vascular } \\
\text { ECs }\end{array}$ & MSCs & PLGA scaffolds & $\begin{array}{l}\text { Neovasculature and } \\
\text { bone formation }\end{array}$ & [203] \\
\hline EPCs & hOBs & PCL-HA scaffolds & $\begin{array}{l}\text { Establishment of } \\
\text { capillary network } \\
\text { and osteoid formation }\end{array}$ & [185] \\
\hline $\begin{array}{l}\text { Adipose tissue } \\
\text { stromal cells }\end{array}$ & $\begin{array}{c}\text { Porous HA ceramic } \\
\text { scaffolds }\end{array}$ & $\begin{array}{c}\text { Formation of ectopic bone } \\
\text { tissue and blood } \\
\text { vessels connected to } \\
\text { host vasculature }\end{array}$ & & [186] \\
\hline
\end{tabular}

\footnotetext{
a)hOBs: primary human osteoblasts, hMSCs: human mesenchymal stem cells, HUVEC: human umbilical vein endothelial cells, HDMEC: human dermal microvascular endothelial cells, EPCs: endothelial progenitor cells. ${ }^{\text {b) }}$ Tutobone ${ }^{\mathbb{R}}$ : processed bovine cancellous bone, PCLHA: polycaprolactone-hydroxiapatite.
} 
implantation vascularization strategy. The co-culture system of ECs and osteoblasts can be used in different ways such as in scaffold-free approaches (e.g., spheroids ${ }^{[181,182]}$ or in conjunction with 3D scaffolds ${ }^{[184,185]}$ (Table 2). Furthermore, fully differentiated mature ${ }^{[183,184]}$ or progenitor cells isolated from several sources ${ }^{[176,182]}$ can make-up the co-culture system. Although normally ECs and osteoblasts are isolated from different sources, from the clinical point of view it is easier to obtain the two cell populations from a common cell source, as has been described for adipose tissue and bone marrow. ${ }^{[185,186]}$

It has been reported by several authors ${ }^{[102,183,184]}$ that ECs co-cultured with osteoblasts are able to establish microcapillary-like structures in a 3D scaffold and that these vascular structures are stable in in vitro culture for up to $42 \mathrm{~d}$ (Figure $3 \mathrm{a}-\mathrm{c}$ ). Furthermore, the complexity of these structures formed by ECs was confirmed by the presence of a patent lumen and by the expression in the perivascular region of type IV collagen, the major constituent of endothelial basement membrane. The great advantage of this strategy is its self-sustainability, i.e., the interaction between the two cell populations recreates the physical and chemical environment favorable for the formation of vascular-like structures, thus obviating the exogenous supply of angiogenic stimuli. Regarding the mechanisms
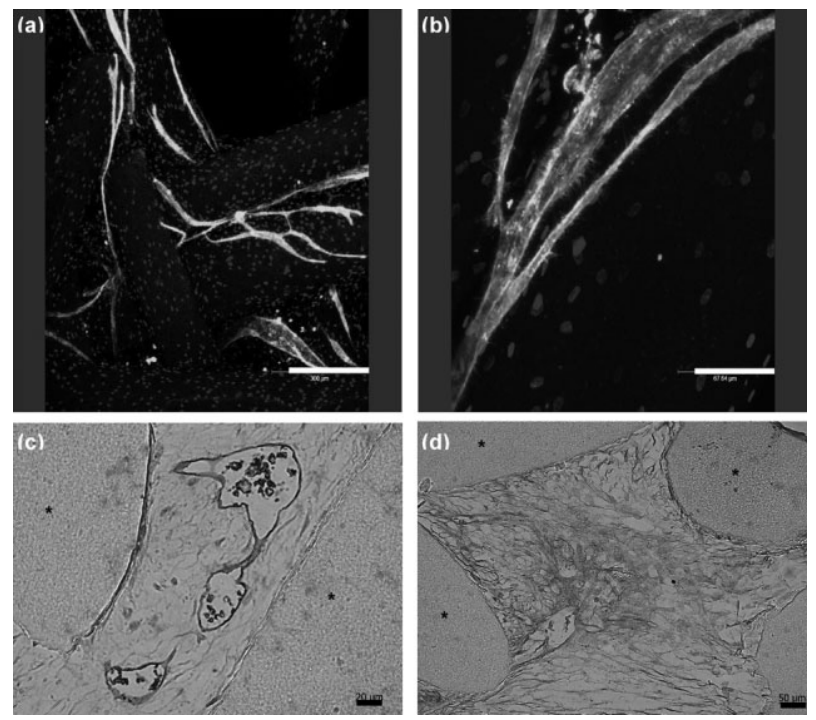

Figure 3. Co-culture system of HDMEC and primary osteoblasts on a SPCL fiber-mesh scaffold. a,b) After 21 days of culture HDMEC organized into microcapillary-like structures with linear and branched forms. In order to distinguish between the two cell populations the sample was stained for $\mathrm{CD}_{31}$ (green fluorescence, endothelial-specific) and nuclei (blue fluorescence, both osteoblasts and HDMECs). c,d) After $35 \mathrm{~d}$ immunohistochemical staining of thin sections of the co-culture system was performed. Sections were stained for the endothelial marker PECAM-1 (CD31) (c) and for collagen type I (d). ${ }^{*}$ Identifies the scaffold material. The values of the scale bars are: a) 300, b) 67, c) 20 , and d) $50 \mu \mathrm{m}$. and factors that underlie the cross-talk communication between ECs and osteoblasts it has been shown ${ }^{[102,183,187]}$ that osteoblasts in co-culture with ECs released higher amounts of the pro-angiogenic factor VEGF than in monoculture. However, in addition to soluble factors, ${ }^{[183]}$ molecules from the $\mathrm{ECM}^{[102,188]}$ play an important role in the orchestration of co-culture. In agreement with other studies of $2 \mathrm{D}$ co-cultures, ${ }^{[55]}$ our group has shown that coculture of human dermal microvascular ECs (HDMECs) with osteoblasts on a SPCL fiber-mesh scaffold triggered collagen type I mRNA and protein synthesis (Figure 3d). ${ }^{[102]}$ Hence, collagen type I is a key molecule and modulator in the coculture system in that it provides chemical and physical cues for migration and proliferation of ECs. In addition, ECs also influence the activity of osteoblasts and up-regulate the expression of alkaline phosphatase (AP), an indicator of the effect of ECs on osteogenic differentiation. ${ }^{[181,189]}$ Another major issue in co-culture is the direct cell-cell contact. Interestingly, when conditioned medium from osteoblasts was added to ECs or when the two cell types were co-cultured physically separated by a filter, no formation of a microcapillary-like structure was observed. ${ }^{[183]}$ Also in support of these findings is the report that changes in the expression of several genes in both cell populations were dependent on cell-to-cell contact and were not seen in conditioned supernatants. ${ }^{[189,190]}$ Connexin-43 (Cx43) is pointed out as the gap junction protein that mediates the intracellular exchanges of regulatory ions and small molecules between ECs and osteoblasts. ${ }^{[56,57]}$ Studies from Villars et al. ${ }^{[57]}$ have confirmed the role of this gap junction in this heterotypic communication by showing that its inhibition decreased the effect of human umbilical vein endothelial cell (HUVEC) co-cultures on hBMSC differentiation.

Long term in vitro co-culture holds the promise that in vitro pre-vascularization might accelerate the establishment of a vascular supply within the implanted scaffold; however, it remains to be determined whether these microcapillary-like structures pre-formed in the biomaterial are able to establish efficient connections with the host microvasculature. An alternative to the in vitro establishment of a microcapillary network is to co-culture ECs and osteoblasts in the scaffolding material for a short time (hours to few days) followed by implantation. This approach takes advantage of the in vivo environment to orchestrate the cellular interaction for the establishment of a functional vasculature. In the work of Yu et al. ${ }^{[185]}$ an implanted co-culture of EPCs and bone marrow-derived osteoblasts on porous PCL not only improved osteogenesis but also enhanced vascularization that consequently prevented the ischemic necrosis at the center of the graft. In contrast, when the same scaffolding material was seeded with osteoblasts alone it impaired osteogenesis and was accompanied by progressive necrosis of the graft. Steffens 
et al. ${ }^{[191]}$ also reported the formation of vasculature after implanting sub-cutaneously into immunodeficient mice a co-culture of mature ECs and osteoblasts on bovine cancelous bone. Specially worth mentioning was the fact that vasculature was stabilized by the recruitment of mural cells and that the newly formed vascular networks anastomosed with the mouse vasculature.

\section{Microsurgery Strategies}

A vascularized graft can be obtained from a hybrid approach that combines microsurgery approaches with bone tissue engineering concepts. Biomaterials, osteogenic cells, and osteoinductive growth factors have been used for the creation of vascularized bone tissues in combination with microsurgery approaches such as flap fabrication and arteriovenous loop. ${ }^{[192]}$ In flap fabrication the engineered structure relies on the extrinsic blood supply, by which vascular ingrowth occurs from the surrounding tissues. ${ }^{\text {[193] }}$ It basically consists of a two-stage surgical procedure, where in the first stage the scaffolding material loaded with cells and/or growth factors is implanted into a site of rich vascularization, usually a muscle or the forearm fascia. ${ }^{[20,194]}$ Capillary ingrowth from the recipient site vascularizes the scaffold, and in the second stage the graft is transferred as free bone flap to the defect and by microvascular surgery the vascular pedicle is anastomosed with vessels at the recipient site. Many researchers have tried to further develop this concept. ${ }^{[195-197]}$ For instance, the clinical studies performed by Warnke et al. ${ }^{\left[{ }^{[0]}\right.}$ took the concept of combining tissue engineering with flap fabrication to a new level. They accomplished mandible reconstruction by combining a custom-made scaffold with bone morphogenetic protein 7 (BMP-7) and the patient's bone marrow. The construct was then implanted into the lastissimus dorsi muscle for 7 weeks and later transferred as a free bone-muscle flap to repair the mandibular defect. The mandible replacement remarkably improved the patient's quality of life and retained its function over 13 months, until the death of the patient from cardiac arrest. ${ }^{[91]}$ Despite the successful outcome of this approach one can not disregard its drawbacks such as the inconvenience of two surgical interventions and donor-site morbidity in sacrificing the attached muscle. ${ }^{[193]}$

Vascularization of porous matrices can also be accomplished by implantation of an arteriovenous loop around the construct. The advantages over flap fabrication is that the arteriovenous loop accomplishes vascular growth with minimal fibrosis, ${ }^{[194]}$ the construct acquires an inherent perfusion, and does not need to rely on favorable local conditions. ${ }^{[192]}$ Kneser et al. ${ }^{[192]}$ reported the induction of axial vascularization in a processed bovine cancelous bone matrix by means of a microsurgically constructed arteriovenous loop. In addition, the induction of vascularization in scaffolding material prior to cell injection may help to increase the initial survival and engraftment of transplanted cells and may consecutively optimize bone formation in bioartificial osteogenic bone tissues. ${ }^{[198]}$ The work of Lokmic et al. ${ }^{[199]}$ took this concept further and developed a model where an arteriovenous loop is placed in a non-collapsible space protected by a polycarbonate chamber aimed to provide a proper vascularized environment for a successful cell transplantation. They hypothesized that the optimal time point for exogenous cell seeding would be in the period of intense angiogenesis, i.e., 7 to 10 days after implantation. However, there are some drawbacks associated to arteriovenous loop; there is the technical challenge of loop fabrication and the donor site morbidity caused by removal of the donor's vein graft. $^{[3,21]}$

\section{Conclusion and Future Challenges}

In the last few years we have observed a shift in the paradigm of bone tissue engineering. The major players have always been osteoblasts and the osteoconductive and/ or inductive properties of the biomaterials, and bone vasculature was typically relegated. Lately, this scenario has been changing, since it became clear that the successful clinical outcome of the implanted cell-constructs is dependent on the establishment of a functional vascular network. Furthermore, a large body of evidence emerged that highlights the crucial role of intraosseous vasculature in bone development, repair, and remodeling. The intricate relation between angiogenesis and osteogenesis has been unveiled and the cross-talk between osteoblasts and ECs was identified as one of the most important cellular interactions that orchestrates bone processes. Several strategies for the acceleration of neovascularization either in vivo or in vitro have been proposed and tested. As revised in this work, it is possible to establish capillary networks by several approaches: by the addition of angiogenic growth factors that elicit an angiogenic response in vivo, by the seeding of mature and progenitor ECs, by the incorporation of microcapillary-like structures into the scaffold design that could provide the necessary physical cues for ECs, by exploring the unique relation between ECs and osteoblasts through co-culture systems, and by combining microsurgery techniques with tissue engineering concepts.

Despite the great achievement that was the establishment of capillary structures on bone constructs, these vascular structures were revealed to be unstable and prone to regression. Hence, at the present moment, efforts are mainly centered on stabilizing neovasculature and thus promoting the formation of long-lasting blood vessels. Perivascular cells such as pericytes and SMCs contribute to the remodeling and maturation of the primitive vascular 
network and are, therefore, fundamental agents in the construction of durable engineered vasculature. In this line of thought, the strategy of dual growth factor delivery encompasses the release of growth factors to promote EC activity and the recruitment of perivascular cells in separate phases. In addition, it is also expected that the complexity of co-culture systems will be upgraded and tricultures that encompass the triad of osteoblasts, ECs, and mural cells will be the adopted system.

An issue equally important to the establishment of microcirculation in the engineered construct is its anastomose with host circulation. If this connection to the recipient's site is not accomplished, the vascularization strategy is jeopardized. The existing technology allows the connection to host vasculature of vessels with a minimum diameter of $1 \mathrm{~mm}$. The solution passes either by the establishment of vessels with larger caliber or by the improvement of vascular surgery techniques.

The reconstruction of lesions that involve both vascular and avascular tissue, such as osteochondral defects, raises a new challenge. The regeneration of osteochondral defects implies not only the development of biphasic systems that meet the distinct mechanical/metabolic requirements of bone and cartilage, but also an integrated system that compartmentalizes and limits vascularization to the bone phase.

The take home message is that bone is a multicomponent system and any successful vascularization strategy of a bone engineered-construct must be able to recreate each of the individual elements and the intricate network of connections between them. All bone tissue engineering strategies must take that into relevant account or they will always be prone to failure.

Acknowledgements: M. I. Santos would like to acknowledge the Portuguese Foundation for Science and Technology (FCT) for her Ph.D. grant (SFRH/BD/13428/2003). This work was partially supported by FCT through funds from POCTI and/or FEDER programs and by the European Union funded STREP Project HIPPOCRATES (NMP3-CT-2003-505758). This work was carried out under the scope of the European NoE EXPERTISSUES (NMP3-CT2004-500283). The authors also acknowledge Gabriela A. Silva for critically reading the manuscript.

Received: March 9, 2009; Revised: June 5, 2009; Accepted: June 8, 2009; Published online: August 17, 2009; DOI: 10.1002/ mabi.200900107

Keywords: biomaterials; bone; fracture repair; tissue engineering; vascularization

[1] A. L. Sieminski, K. J. Gooch, Biomaterials 2000, 21, 2232.

[2] G. F. Muschler, C. Nakamoto, L. G. Griffith, J. Bone Joint Surg. Am. 2004, 86-A, 1541.

[3] O. C. Cassell, S. O. Hofer, W. A. Morrison, K. R. Knight, Br. J. Plast. Surg. 2002, 55, 603.
[4] M. Nomi, A. Atala, P. D. Coppi, S. Soker, Mol. Aspects Med. 2002, 23, 463

[5] H. Yu, P. J. VandeVord, L. Mao, H. W. Matthew, P. H. Wooley, S. Y. Yang, Biomaterials 2009, 30, 508.

[6] N. Koike, D. Fukumura, O. Gralla, P. Au, J. S. Schechner, R. K. Jain, Nature 2004, 428, 138.

[7] S. H. Lee, R. N. Coger, M. G. Clemens, Tissue Eng. 2006, 12, 2825.

[8] J. E. Davies, Int. J. Prosthodontics 1998, 11, 391.

[9] K. A. Landman, A. O. Cai, Bull. Math. Biol. 2007, 69, 2405.

[10] E. Sachlos, J. T. Czernuszka, Eur. Cell. Mater. 2003, 5, 29.

[11] S. H. Oh, C. L. Ward, A. Atala, J. J. Yoo, B. S. Harrison, Biomaterials 2009, 30, 757.

[12] E. Volkmer, I. Drosse, S. Otto, A. Stangelmayer, M. Stengele, B. C. Kallukalam, W. Mutschler, M. Schieker, Tissue Eng., Part A 2008, 14, 1331.

[13] M. E. Gomes, V. I. Sikavitsas, E. Behravesh, R. L. Reis, A. G. Mikos, J. Biomed. Mater. Res. 2003, 67A, 87.

[14] A. Probst, H. U. Spiegel, J. Invest. Surg. 1997, 10, 77.

[15] H. P. Greisler, Atherosclerosis Suppl. 2003, 4, 265.

[16] F. Arnold, D. C. West, Pharmacol. Ther. 1991, 52, 407.

[17] A. G. Mikos, G. Sarakinos, M. D. Lyman, D. E. Ingber, J. P. Vacanti, R. Langer, Biotechnol. Bioeng. 1993, 42, 716.

[18] D. W. Hutmacher, Biomaterials 2000, 21, 2529.

[19] M. S. Taylor, A. U. Daniels, K. P. Andriano, J. Heller, J. Appl. Biomater. 1994, 5, 151.

[20] O. Scheufler, D. J. Schaefer, C. Jaquiery, A. Braccini, D. J. Wendt, J. A. Gasser, R. Galli, G. Pierer, M. Heberer, I. Martin, J. Cell. Mol. Med. 2008, 12, 1238.

[21] Z. M. Lokmic, G. M. Mitchell, Tissue Eng., Part B 2008, 14, 87.

[22] J. M. Kanczler, R. O. Oreffo, Eur. Cell. Mater. 2008, 15, 100.

[23] U. I. Chung, H. Kawaguchi, T. Takato, K. Nakamura, J. Orthop. Sci. 2004, 9, 410.

[24] C. E. Clarkin, R. J. Emery, A. A. Pitsillides, C. P. Wheeler-Jones, J. Cell. Physiol. 2008, 214, 537.

[25] H. P. Gerber, N. Ferrara, Trends Cardiovasc. Med. 2000, 10, 223.

[26] P. Collin-Osdoby, J. Cell. Biochem. 1994, 55, 304.

[27] N. Ortega, D. J. Behonick, Z. Werb, Trends Cell. Biol. 2004, 14, 86.

[28] K. Red-Horse, Y. Crawford, F. Shojaei, N. Ferrara, Dev. Cell. 2007, 12, 181.

[29] B. E. Sumpio, J. T. Riley, A. Dardik, Int. J. Biochem. Cell. Biol. 2002, 34, 1508.

[30] C. Garlanda, E. Dejana, Arterioscler. Thromb. Vasc. Biol. 1997, 17, 1193.

[31] I. McCarthy, J. Bone Joint Surg. Am. 2006, 88, Suppl 3, 4.

[32] M. L. Brandi, P. Collin-Osdoby, J. Bone Miner. Res. 2006, 21, 183.

[33] J. Trueta, J. Bone Joint Surg. - British Volume 1963, 45, 402.

[34] E. O. Johnson, K. Soultanis, P. N. Soucacos, Orthop. Clin. North Am. 2004, 35, 285.

[35] D. W. Hutmacher, M. Sittinger, Tissue Eng. 2003, 9, Suppl 1, S45.

[36] M. Laroche, Joint Bone Spine 2002, 69, 262.

[37] K. Draenert, Y. Draenert, Scan. Electron. Microsc. 1980, 113.

[38] A. Wilson, A. Trumpp, Nat. Rev. Immunol. 2006, 6, 93.

[39] G. Karsenty, Nat. Med. 2000, 6, 970.

[40] O. Barou, S. Mekraldi, L. Vico, G. Boivin, C. Alexandre, M. H. Lafage-Proust, Bone 2002, 30, 604.

[41] R. E. Marx, Oral Maxillofac. Surg. Clin. North Am. 2007, 19, 455. 
[42] C. A. Migliorati, J. Casiglia, J. Epstein, P. L. Jacobsen, M. A. Siegel, S. B. Woo, J. Am. Dent. Assoc. 2005, 136, 1658.

[43] T. J. Martin, E. Seeman, Best Pract. Res. Clin. Endocrinol. Metab. 2008, 22, 701.

[44] G. L. Barnes, P. J. Kostenuik, L. C. Gerstenfeld, T. A. Einhorn, J. Bone Miner. Res. 1999, 14, 1805.

[45] J. Malda, T. J. Klein, Z. Upton, Tissue Eng. 2007, 13, 2153.

[46] D. V. Faller, Clin. Exp. Pharmacol. Physiol. 1999, 26, 74.

[47] S. Kourembanas, R. L. Hannan, D. V. Faller, J. Clin. Invest. $1990,86,670$

[48] R. A. Carano, E. H. Filvaroff, Drug Discov. Today 2003, 8 , 980.

[49] A. Schindeler, M. M. McDonald, P. Bokko, D. G. Little, Semin. Cell Dev. Biol. 2008, 19, 459.

[50] N. Hansen-Algenstaedt, C. Joscheck, L. Wolfram, C. Schaefer, I. Muller, A. Bottcher, G. Deuretzbacher, L. Wiesner, M. Leunig, P. Algenstaedt, W. Ruther, Acta Orthopaedica 2006, 77, 429.

[51] C. Ferguson, E. Alpern, T. Miclau, J. A. Helms, Mechanisms of Development 1999, 87, 57.

[52] A. X. Le, T. Miclau, D. Hu, J. A. Helms, J. Orthop. Res. 2001, 19, 78.

[53] T. D. Fang, A. Salim, W. Xia, R. P. Nacamuli, S. Guccione, H. M. Song, R. A. Carano, E. H. Filvaroff, M. D. Bednarski, A. J. Giaccia, M. T. Longaker, J. Bone Mineral Res. 2005, 20, 1114.

[54] I. H. Choi, C. Y. Chung, T. J. Cho, W. J. Yoo, J. Korean Med. Sci. 2002, 17, 435

[55] F. Villars, L. Bordenave, R. Bareille, J. Amedee, J. Cell Biochem. 2000, 79, 672.

[56] B. Guillotin, C. Bourget, M. Remy-Zolgadri, R. Bareille, P. Fernandez, V. Conrad, J. Amedee-Vilamitjana, Cell. Physiol. Biochem. 2004, 14, 325.

[57] F. Villars, B. Guillotin, T. Amedee, S. Dutoya, L. Bordenave, R. Bareille, J. Amedee, Am. J. Physiol., Cell Physiol. 2002, 282, C775.

[58] J. A. Spector, B. J. Mehrara, J. A. Greenwald, P. B. Saadeh, D. S. Steinbrech, P. J. Bouletreau, L. P. Smith, M. T. Longaker, Am. J. Physiol., Cell Physiol. 2001, 280, C72.

[59] J. Street, M. Bao, L. deGuzman, S. Bunting, F. V. Peale, Jr., N. Ferrara, H. Steinmetz, J. Hoeffel, J. L. Cleland, A. Daugherty, N. van Bruggen, H. P. Redmond, R. A. Carano, E. H. Filvaroff, Proc. Natl. Acad. Sci. USA 2002, 99, 9656.

[60] G. T. Stavri, I. C. Zachary, P. A. Baskerville, J. F. Martin, J. D. Erusalimsky, Circulation 1995, 92, 11.

[61] U. Mayr-Wohlfart, J. Waltenberger, H. Hausser, S. Kessler, K. P. Gunther, C. Dehio, W. Puhl, R. E. Brenner, Bone 2002, 30, 472.

[62] V. Midy, J. Plouet, Biochem. Biophys. Res. Commun. 1994, 199 , 380

[63] M. M. L. Deckers, M. Karperien, C. van der Bent, T. Yamashita, S. E. Papapoulos, C. W. G. M. Lowik, Endocrinology 2000, 141, 1667.

[64] H. Tokuda, K. Hirade, X. Wang, Y. Oiso, O. Kozawa, J. Endocrin. 2003, 177, 101.

[65] P. Collin-Osdoby, L. Rothe, S. Bekker, F. Anderson, Y. Huang, P. Osdoby, J. Bone Miner. Res. 2002, 17, 1859.

[66] P. B. Saadeh, B. J. Mehrara, D. S. Steinbrech, J. A. Spector, J. A. Greenwald, G. S. Chin, H. Ueno, G. K. Gittes, M. T. Longaker, Endocrinology 2000, 141, 2075.

[67] H. P. von Schroeder, C. J. Veillette, J. Payandeh, A. Qureshi, J. N. Heersche, Bone 2003, 33, 673.

[68] P. J. Bouletreau, S. M. Warren, J. A. Spector, Z. M. Peled, R. P. Gerrets, J. A. Greenwald, M. T. Longaker, Plast. Reconstr. Surg. 2002, 109, 2384
[69] A. Yamaguchi, T. Ishizuya, N. Kintou, Y. Wada, T. Katagiri, J. M. Wozney, V. Rosen, S. Yoshiki, Biochem. Biophys. Res. Commun. 1996, 220, 366.

[70] P. J. Bouletreau, S. M. Warren, J. A. Spector, D. S. Steinbrech, B. J. Mehrara, M. T. Longaker, Plastic Reconstructive Surg. 2002, 110, 139.

[71] J. O. Hollinger, C. E. Hart, S. N. Hirsch, S. Lynch, G. E. Friedlaender, J. Bone Joint Surg. Am. 2008, 90, Suppl 1, 48.

[72] D. L. Goad, J. Rubin, H. Wang, A. H. Tashjian, Jr., C. Patterson, Endocrinology 1996, 137, 2262.

[73] M. M. L. Deckers, R. L. van Bezooijen, G. van der Horst, J. Hoogendam, C. van der Bent, S. E. Papapoulos, C. W. G. M. Lowik, Endocrinology 2002, 143, 1545.

[74] P. B. Saadeh, B. J. Mehrara, D. S. Steinbrech, M. E. Dudziak, J. A. Greenwald, J. S. Luchs, J. A. Spector, H. Ueno, G. K. Gittes, M. T. Longaker, Am. J. Physiol., Cell Physiol. 1999, 277, C628.

[75] C. J. H. Veillette, H. P. von Schroeder, Bone 2004, 34, 288.

[76] S. M. Warren, D. S. Steinbrech, B. J. Mehrara, P. B. Saadeh, J. A. Greenwald, J. A. Spector, P. J. Bouletreau, M. T. Longaker, J. Surg. Res. 2001, 99, 147.

[77] S. Kourembanas, P. A. Marsden, L. P. McQuillan, D. V. Faller, J. Clin. Invest. 1991, 88, 1054.

[78] R. Humar, F. N. Kiefer, H. Berns, T. J. Resink, E. J. Battegay, Faseb. J. 2002, 16, 771.

[79] D. S. Steinbrech, B. J. Mehrara, P. B. Saadeh, J. A. Greenwald, J. A. Spector, G. K. Gittes, M. T. Longaker, Ann. Plast. Surg. 2000, 44, 529.

[80] D. S. Steinbrech, B. J. Mehrara, P. B. Saadeh, G. Chin, M. E. Dudziak, R. P. Gerrets, G. K. Gittes, M. T. Longaker, Plast. Reconstr. Surg. 1999, 104, 738.

[81] A. Minchenko, J. Caro, Mol. Cell. Biochem. 2000, 208, 53.

[82] K. Peters, H. Schmidt, R. E. Unger, G. Kamp, F. Prols, B. J. Berger, C. J. Kirkpatrick, Mol. Cell. Biochem. 2005, 270, 157.

[83] E. Brogi, T. Wu, A. Namiki, J. M. Isner, Circulation 1994, 90 , 649.

[84] Y. Xu, P. Malladi, M. Chiou, E. Bekerman, A. J. Giaccia, M. T. Longaker, Tissue Eng. 2007, 13, 2981.

[85] S. C. Hung, R. R. Pochampally, S. C. Hsu, C. Sanchez, S. C. Chen, J. Spees, D. J. Prockop, PLOS ONE 2007, 2, 416.

[86] W. S. Khan, A. B. Adesida, T. E. Hardingham, Arthritis Res. Ther. 2007, 9, R55.

[87] S. M. Villarruel, C. A. Boehm, M. Pennington, J. A. Bryan, K. A. Powell, G. F. Muschler, J. Orthop. Res. 2008, 26, 1390.

[88] E. Potier, E. Ferreira, A. Meunier, L. Sedel, D. Logeart-Avramoglou, H. Petite, Tissue Eng. 2007, 13, 1325.

[89] J. C. Utting, S. P. Robins, A. Brandao-Burch, I. R. Orriss, J. Behar, T. R. Arnett, Exp. Cell. Res. 2006, 312, 1693.

[90] P. H. Warnke, I. N. Springer, J. Wiltfang, Y. Acil, H. Eufinger, M. Wehmoller, P. A. Russo, H. Bolte, E. Sherry, E. Behrens, H. Terheyden, Lancet 2004, 364, 766.

[91] P. H. Warnke, J. Wiltfang, I. Springer, Y. Acil, H. Bolte, M. Kosmahl, P. A. J. Russo, E. Sherry, U. Lutzen, S. Wolfart, H. Terheyden, Biomaterials 2006, 27, 3163.

[92] A. T. Bishop, M. Pelzer, Orthop. Clin. North Am. 2007, 38 , 109.

[93] A. M. Martins, M. I. Santos, H. S. Azevedo, P. B. Malafaya, R. L. Reis, Acta Biomater. 2008.

[94] M. E. Gomes, H. L. Holtorf, R. L. Reis, A. G. Mikos, Tissue Eng. 2006, 12, 801.

[95] V. Karageorgiou, D. Kaplan, Biomaterials 2005, 26, 5474.

[96] D. Narayan, S. S. Venkatraman, J. Biomed. Mater. Res. A 2008.

[97] W. Bonfield, Philos. Trans. A: Math Phys. Eng. Sci. 2006, 364, 227. 
[98] K. Tuzlakoglu, N. Bolgen, A. J. Salgado, M. E. Gomes, E. Piskin, R. L. Reis, J. Mater. Sci. Mater. Med. 2005, 16, 1099.

[99] M. E. Gomes, H. S. Azevedo, A. R. Moreira, V. Ella, M. Kellomaki, R. L. Reis, J. Tissue Eng. Regen. Med. 2008, 2, 243.

[100] M. E. Gomes, C. M. Bossano, C. M. Johnston, R. L. Reis, A. G. Mikos, Tissue Eng. 2006, 12, 177.

[101] M. P. Pavlov, J. F. Mano, N. M. Neves, R. L. Reis, Macromol. Biosci. 2004, 4, 776

[102] M. I. Santos, R. Unger, R. A. Sousa, R. L. Reis, C. J. Kirkpatrick, Tissue Eng., Part A 2008, 14, 712.

[103] K. Tuzlakoglu, I. Pashkuleva, M. R. Rodrigues, v, L. Gomes, R. Müller, R. L. Reis, J. Biomed. Mater. Res.: Part A 2008, DOI: 10.1002/jbm.a.32358.

[104] G. E. Davis, D. R. Senger, Circ. Res. 2005, 97, 1093.

[105] H. Yang, S. Yang, X. Chi, J. R. G. Evans, J. Biomed. Mater. Res., Part B: Appl. Biomater. 2006, 79B, 116.

[106] L. M. Bellan, S. P. Singh, P. W. Henderson, T. J. Porri, H. G. Craighead, J. A. Spector, Soft Matter 2009, 5, 1354.

[107] J. T. Borenstein, E. J. Weinberg, B. K. Orrick, C. Sundback, M. R. Kaazempur-Mofrad, J. P. Vacanti, Tissue Eng. 2007, 13, 1837.

[108] M. Shin, K. Matsuda, O. Ishii, H. Terai, M. KaazempurMofrad, J. Borenstein, M. Detmar, J. P. Vacanti, Biomed. Microdevices 2004, 6, 269.

[109] G. J. Wang, Y. F. Hsu, Biomed. Microdevices 2006, 8, 51.

[110] C. Fidkowski, M. R. Kaazempur-Mofrad, J. Borenstein, J. P. Vacanti, R. Langer, Y. Wang, Tissue Eng. 2005, 11, 302.

[111] Y. Tsuda, M. Yamato, A. Kikuchi, M. Watanabe, G. P. Chen, Y. Takahashi, T. Okano, Adv. Mater. 2007, 19, 3633.

[112] A. Ovsianikov, A. Ostendorf, B. N. Chichkov, Appl. Surf. Sci. 2007, 253, 6599.

[113] A. Ovsianikov, S. Schlie, A. Ngezahayo, A. Haverich, B. N. Chichkov, J. Tissue Eng. Regen. Med. 2007, 1, 443.

[114] L. Ciocca, F. De Crescenzio, M. Fantini, R. Scotti, Comput. Med. Imaging Graph. 2009, 33, 58.

[115] L. Moroni, R. Schotel, J. Sohier, J. R. de Wijn, C. A. van Blitterswijk, Biomaterials 2006, 27, 5918.

[116] J. Dai, A. B. M. Rabie, J. Dent. Res. 2007, 86, 937.

[117] T. Tarkka, A. Sipola, T. Jamsa, Y. Soini, S. Yla-Herttuala, J. Tuukkanen, T. Hautala, J. Gene Med. 2003, 5, 560.

[118] R. R. Chen, E. A. Silva, W. W. Yuen, D. J. Mooney, Pharmaceutical Research 2007, 24, 258.

[119] A. H. Zisch, M. P. Lutolf, J. A. Hubbell, Cardiovasc. Pathol. 2003, 12, 295.

[120] S. Takeshita, L. P. Zheng, E. Brogi, M. Kearney, L. O. Pu, S. Bunting, N. Ferrara, J. F. Symes, J. M. Isner, J. Clin. Invest. 1994, 93, 662.

[121] Y. M. Elcin, V. Dixit, G. Gitnick, Artif. Cells Blood Substit. Immobil. Biotechnol. 1996, 24, 257.

[122] S. E. Sakiyama-Elbert, J. A. Hubbell, J. Controlled Release 2000, 65, 389.

[123] M. Tanihara, Y. Suzuki, E. Yamamoto, A. Noguchi, Y. Mizushima, J. Biomed. Mater. Res. 2001, 56, 216.

[124] J. S. Pieper, T. Hafmans, P. B. van Wachem, M. J. van Luyn, L. A. Brouwer, J. H. Veerkamp, T. H. van Kuppevelt, J. Biomed. Mater. Res. 2002, 62, 185

[125] J. Y. Lee, S. H. Nam, S. Y. Im, Y. J. Park, Y. M. Lee, Y. J. Seol, C. P. Chung, S. J. Lee, J. Controlled Release 2002, 78, 187.

[126] G. A. Silva, O. P. Coutinho, P. Ducheyne, I. M. Shapiro, R. L. Reis, Tissue Eng. 2007, 13, 1259.

[127] P. B. Malafaya, G. A. Silva, R. L. Reis, Adv. Drug Delivery Rev. 2007, 59, 207.
[128] D. Kaigler, Z. Wang, K. Horger, D. J. Mooney, P. H. Krebsbach, J. Bone Miner. Res. 2006, 21, 735.

[129] G. A. Silva, F. J. Costa, O. P. Coutinho, S. Radin, P. Ducheyne, R. L. Reis, J. Biomed. Mater. Res. A 2004, 70A, 442.

[130] W. L. Murphy, C. A. Simmons, D. Kaigler, D. J. Mooney, J. Dent Res. 2004, 83, 204

[131] E. Lerouxel, P. Weiss, B. Giumelli, A. Moreau, P. Pilet, J. Guicheux, P. Corre, J. M. Bouler, G. Daculsi, O. Malard, Biomaterials 2006, 27, 4566.

[132] J. Barralet, U. Gbureck, P. Habibovic, E. Vorndran, C. Gerard, C. J. Doillon, Tissue Eng., Part A 2009, 15, 1601.

[133] R. Li, D. J. Stewart, H. P. von Schroeder, E. S. Mackinnon, E. H. Schemitsch, J. Orthop. Res. 2008.

[134] N. Davies, S. Dobner, D. Bezuidenhout, C. Schmidt, M. Beck, A. H. Zisch, P. Zilla, Biomaterials 2008.

[135] N. I. Moldovan, M. Ferrari, Arch. Pathol. Lab. Med. 2002, 126, 320.

[136] S. P. Massia, J. A. Hubbell, J. Biomed. Mater. Res. 1991, 25 , 223.

[137] Y. Hamada, K. Nokihara, M. Okazaki, W. Fujitani, T. Matsumoto, M. Matsuo, Y. Umakoshi, J. Takahashi, N. Matsuura, Biochem. Biophys. Res. Commun. 2003, 310, 153.

[138] D. S. Grant, J. L. Kinsella, R. Fridman, R. Auerbach, B. A. Piasecki, Y. Yamada, M. Zain, H. K. Kleinman, J. Cell Physiol. 1992, 153, 614

[139] J. A. Hubbell, Curr. Opin. Biotechnol. 1999, 10, 123.

[140] Y. Hamada, K. Yuki, M. Okazaki, W. Fujitani, T. Matsumoto, M. K. Hashida, K. Harutsugu, K. Nokihara, M. Daito, N. Matsuura, J. Takahashi, Dent. Mater. J. 2004, 23, 650.

[141] Y. Hamada, H. Egusa, Y. Kaneda, I. Hirata, N. Kawaguchi, T. Hirao, T. Matsumoto, M. Yao, K. Daito, M. Suzuki, H. Yatani, M. Daito, M. Okazaki, N. Matsuura, Dent. Mater. J. 2007, 26, 487.

[142] S. P. Massia, J. A. Hubbell, J. Biol. Chem. 1992, 267, 14019.

[143] L. S. Sefcik, C. E. Petrie Aronin, K. A. Wieghaus, E. A. Botchwey, Biomaterials 2008, 29, 2869.

[144] O. Kilian, V. Alt, C. Heiss, T. Jonuleit, E. Dingeldein, I. Flesch, U. Fidorra, S. Wenisch, R. Schnettler, Growth Factors 2005, 23, 125.

[145] O. Kilian, S. Wenisch, S. Karnati, E. Baumgart-Vogt, A. Hild, R. Fuhrmann, T. Jonuleit, E. Dingeldein, R. Schnettler, R. P. Franke, Biomaterials 2008, 29, 3429.

[146] S. T. Nillesen, P. J. Geutjes, R. Wismans, J. Schalkwijk, W. F. Daamen, T. H. van Kuppevelt, Biomaterials 2007, 28, 1123.

[147] Y. C. Huang, D. Kaigler, K. G. Rice, P. H. Krebsbach, D. J. Mooney, J. Bone Miner. Res. 2005, 20, 848.

[148] T. P. Richardson, M. C. Peters, A. B. Ennett, D. J. Mooney, Nat. Biotechnol. 2001, 19, 1029.

[149] E. Jabbarzadeh, T. Jiang, M. Deng, L. S. Nair, Y. M. Khan, C. T. Laurencin, Biotechnol. Bioeng. 2007, 98, 1094.

[150] M. I. Santos, S. Fuchs, M. E. Gomes, R. E. Unger, R. L. Reis, C. J. Kirkpatrick, Biomaterials 2007, 28, 240.

[151] R. E. Unger, K. Peters, O. Huang, A. Funk, D. Paul, C. J. Kirkpatrick, Biomaterials 2005, 26, 3461.

[152] A. C. Breithaupt-Faloppa, J. Kleinheinz, O. Crivello, Jr., J. Biomed. Mater. Res., B: Appl. Biomater. 2006, 76, 49.

[153] R. E. Unger, K. Peters, M. Wolf, A. Motta, C. Migliaresi, C. J. Kirkpatrick, Biomaterials 2004, 25, 5137.

[154] C. S. Choong, D. W. Hutmacher, J. T. Triffitt, Tissue Eng. 2006, 12, 2521.

[155] C. F. Chu, A. Lu, M. Liszkowski, R. Sipehia, Biochim. Biophys. Acta 1999, 1472, 479.

[156] C. Boura, S. Muller, D. Vautier, D. Dumas, P. Schaaf, J. Claude Voegel, J. Francois Stoltz, P. Menu, Biomaterials 2005, 26, 4568 . 
[157] R. E. Unger, O. Huang, K. Peters, D. Protzer, D. Paul, C. J. Kirkpatrick, Biomaterials 2005, 26, 1877.

[158] M. I. Santos, I. Pashkuleva, C. M. Alves, M. E. Gomes, S. Fuchs, R. E. Unger, R. L. Reis, C. J. Kirkpatrick, J. Mater. Chem. 2009, 19, 4091.

[159] Z. Ma, M. Kotaki, T. Yong, W. He, S. Ramakrishna, Biomaterials 2005, 26, 2527

[160] I. Pashkuleva, A. P. Marques, F. Vaz, R. L. Reis, J. Mater. Sci. Mater. Med. 2005, 16, 81.

[161] W. D. Holder, H. E. Gruber, W. D. Roland, A. L. Moore, C. R. Culberson, A. B. Loebsack, K. J. L. Burg, D. J. Mooney, Tissue Eng. 1997, 3, 149.

[162] J. E. Nor, M. C. Peters, J. B. Christensen, M. M. Sutorik, S. Linn, M. K. Khan, C. L. Addison, D. J. Mooney, P. J. Polverini, Lab. Invest. 2001, 81, 453.

[163] J. S. Schechner, A. K. Nath, L. Zheng, M. S. Kluger, C. C. Hughes, M. R. Sierra-Honigmann, M. I. Lorber, G. Tellides, M. Kashgarian, A. L. Bothwell, J. S. Pober, Proc. Natl. Acad. Sci. USA 2000, 97, 9191.

[164] S. Kim, H. von Recum, Tissue Eng. Part B. Rev. 2008, 14, 133.

[165] N. Laurens, in Methods in Endothelial Cell Biology, H. G. Augustin, Ed., Springer, Heidelberg 2004, p. 3.

[166] J. T. Chi, H. Y. Chang, G. Haraldsen, F. L. Jahnsen, O. G. Troyanskaya, D. S. Chang, Z. Wang, S. G. Rockson, M. Van de Rijn, D. Botstein, P. O. Brown, Proc. Natl. Acad. Sci. USA 2003, 100, 10623.

[167] A. Luttun, G. Carmeliet, P. Carmeliet, Trends Cardiovasc. Med. 2002, 12, 88.

[168] M. Hristov, W. Erl, P. C. Weber, Trends Cardiovasc. Med. 2003, 13, 201.

[169] X. Wu, E. Rabkin-Aikawa, K. J. Guleserian, T. E. Perry, Y. Masuda, F. W. H. Sutherland, F. J. Schoen, J. E. Mayer, J. Bischoff, Am. J. Physiol., Heart Circ. Physiol. 2004, 287, $\mathrm{H} 480$.

[170] A. N. Veleva, D. E. Heath, S. L. Cooper, C. Patterson, Biomaterials 2008, 29, 3656.

[171] S. Fuchs, M. I. Hermanns, C. J. Kirkpatrick, Cell Tissue Res. 2006, 326, 79 .

[172] C. H. Yoon, J. Hur, K. W. Park, J. H. Kim, C. S. Lee, I. Y. Oh, T. Y. Kim, H. J. Cho, H. J. Kang, I. H. Chae, H. K. Yang, B. H. Oh, Y. B. Park, H. S. Kim, Circulation 2005, 112, 1618.

[173] S. Fuchs, A. Motta, C. Migliaresi, C. J. Kirkpatrick, Biomaterials 2006, 27, 5399.

[174] T. Matsumoto, A. Kawamoto, R. Kuroda, M. Ishikawa, Y. Mifune, H. Iwasaki, M. Miwa, M. Horii, S. Hayashi, A. Oyamada, H. Nishimura, S. Murasawa, M. Doita, M. Kurosaka, T. Asahara, Am. J. Pathol. 2006, 169, 1440.

[175] T. Matsumoto, R. Kuroda, Y. Mifune, A. Kawamoto, T. Shoji, M. Miwa, T. Asahara, M. Kurosaka, Bone 2008, 43, 434.

[176] Y. Mifune, T. Matsumoto, A. Kawamoto, R. Kuroda, T. Shoji, H. Iwasaki, S. M. Kwon, M. Miwa, M. Kurosaka, T. Asahara, Stem Cells 2008, 26, 1395.

[177] J. M. Melero-Martin, Z. A. Khan, A. Picard, X. Wu, S. Paruchuri, J. Bischoff, Blood 2007, 109, 4761.

[178] P. Au, L. M. Daheron, D. G. Duda, K. S. Cohen, J. A. Tyrrell, R. M. Lanning, D. Fukumura, D. T. Scadden, R. K. Jain, Blood 2008, $111,1302$.
[179] J. M. Melero-Martin, M. E. De Obaldia, S. Y. Kang, Z. A. Khan, L. Yuan, P. Oettgen, J. Bischoff, Circulation Research 2008, 103, 194.

[180] S. Fuchs, S. Ghanaati, C. Orth, M. Barbeck, M. Kolbe, A. Hofmann, M. Eblenkamp, M. Gomes, R. L. Reis, C. J. Kirkpatrick, Biomaterials 2009, 30, 526.

[181] J. Rouwkema, J. De Boer, C. A. Van Blitterswijk, Tissue Eng. 2006, 12, 2685.

[182] S. Fuchs, A. Hofmann, C. J. Kirkpatrick, Tissue Eng. 2007, 13 2577.

[183] R. E. Unger, A. Sartoris, K. Peters, A. Motta, C. Migliaresi, M. Kunkel, U. Bulnheim, J. Rychly, C. J. Kirkpatrick, Biomaterials 2007, 28, 3965.

[184] A. Hofmann, U. Ritz, S. Verrier, D. Eglin, M. Alini, S. Fuchs, C. J. Kirkpatrick, P. M. Rommens, Biomaterials 2008, 29, 4217.

[185] H. Yu, P.J. Vandevord, W. Gong, B. Wu, Z. Song, H. W. Matthew, P. H. Wooley, S. Y. Yang, J. Orthop. Res. 2008, 26, 1147

[186] A. Scherberich, R. Galli, C. Jaquiery, J. Farhadi, I. Martin, Stem Cells 2007, 25, 1823.

[187] D. Kaigler, P. H. Krebsbach, P. J. Polverini, D. J. Mooney, Tissue Eng. 2003, 9, 95.

[188] S. Fuchs, X. Jiang, H. Schmidt, E. Dohle, S. Ghanaati, C. Orth A. Hofmann, A. Motta, C. Migliaresi, C. J. Kirkpatrick, Biomaterials, 2009, 30, 1329.

[189] A. Stahl, A. Wenger, H. Weber, G. B. Stark, H. G. Augustin, G. Finkenzeller, Biochem. Biophys. Res. 2004, 322, 684.

[190] G. Finkenzeller, G. Arabatzis, M. Geyer, A. Wenger, H. Bannasch, G. B. Stark, Tissue Eng. 2006, 12, 2889.

[191] L. Steffens, A. Wenger, G. B. Stark, G. Finkenzeller, J. Cell Mol Med. 2008.

[192] U. Kneser, D. J. Schaefer, E. Polykandriotis, R. E. Horch, J. Cell. Mol. Med. 2006, 10, 7

[193] L. L. Ren, D. Y. Ma, X. Feng, T. O. Mao, Y. P. Liu, Y. Ding, Med, Hypotheses 2008.

[194] E. Polykandriotis, A. Arkudas, R. E. Horch, M. Sturzl, U. Kneser, J. Cell. Mol. Med. 2007, 11, 6.

[195] F. Casabona, I. Martin, A. Muraglia, P. Berrino, P. Santi, R. Cancedda, R. Quarto, Plast. Reconstr. Surg. 1998, 101, 577.

[196] P. Pelissier, F. Villars, S. Mathoulin-Pelissier, R. Bareille, M. H. Lafage-Proust, J. Vilamitjana-Amedee, Plast. Reconstr. Surg. 2003, 111, 1932.

[197] O. Scheufler, D. J. Schaefer, C. Jaquiery, A. Braccini, D. J. Wendt, J. A. Gassen, R. Galli, G. Pierer, M. Heberer, I. Martin, J. Cell. Mol. Med. 2007, 12, 1238.

[198] U. Kneser, E. Polykandriotis, J. Ohnolz, K. Heidner, L. Grabinger, S. Euler, K. U. Amann, A. Hess, K. Brune, P. Greil, M. Sturzl, R. E. Horch, Tissue Eng. 2006, 12, 1721.

[199] Z. Lokmic, F. Stillaert, W. A. Morrison, E. W. Thompson, G. M. Mitchell, Faseb. J. 2007, 21, 511.

[200] G. Wang, C. Chen, S. Hsu, Y. Chiang, Microsystem Technol. 2005, 12, 120.

[201] K. Dong Hyuck, M. Jyoti, J. Laser Appl. 2008, 20, 185.

[202] A. Wenger, A. Stahl, H. Weber, G. Finkenzeller, H. G. Augustin, G. B. Stark, U. Kneser, Tissue Eng. 2004, 10, 1536.

[203] H. Sun, Z. Ou, Y. Guo, G. Zang, B. Yang, Biomed. Eng. Online 2007, 6, 41 